\title{
Unbalanced growth in natural assemblages of marine bacterioplankton
}

\author{
Gerardo Chin-Leo*, David L. Kirchman \\ College of Marine Studies, University of Delaware, Lewes, Delaware 19958, USA
}

\begin{abstract}
We tested whether natural assemblages of marine bacterioplankton undergo periods when rates of macromolecular syntheses are uncoupled (unbalanced growth). In seawater cultures of bacteria, rates of DNA and protein syntheses (thymidine and leucine incorporation) and changes in the DNA amount and cell size were compared to fluctuations in growth rate. Rates of DNA and protein syntheses became uncoupled when the bacterial assemblage shifted between growth rates. During these periods of unbalanced growth, rates of bacterial protein synthesis changed faster than rates of DNA synthesis. Variations in the DNA concentration and size of cells paralleled changes in rates of DNA and protein syntheses. The C:DNA ratio of bacteria varied 2-fold depending on the growth state with an average value of $4.6 \pm 0.48$. The delay between unbalanced growth and shifts in the growth rate was on the order of hours and was always shorter than the generation time. Information about unbalanced growth may reveal the delay between fluctuations in the environment and the corresponding bacterial response. In addition, the unbalanced growth model may explain why rates of thymidine and leucine incorporation occasionally do not covary in pelagic ecosystems.
\end{abstract}

\section{INTRODUCTION}

Because pelagic heterotrophic bacteria can process up to $50 \%$ of the carbon fixed by photosynthesis in many aquatic systems (Ducklow 1983, Cole et al. 1988), understanding the controls of bacterial growth is necessary in examining the flow of carbon and energy. Bacterial production appears to be primarily regulated by phytoplankton production in various environments as there is a positive correlation between these parameters (Cole et al. 1988). Also, the ratio of bacterial production to primary production is relatively constant, even at high rates of primary production (Cole et al. 1988). However, this correlation between bacterial and phytoplankton production is based on averages over large spatial scales or over seasons (Cole et al. 1988). The relationship between phytoplankton and bacterial production can vary greatly, particularly over shorter temporal and spatial scales (e.g. McManus \& Peterson 1988). Growth of bacteria on allochthonous inputs of organic carbon and the temporary lags in grazing

\footnotetext{
- Present address: University of Texas at Austin, Marine Science Institute, Port Aransas, Texas 78373, USA
}

pressure on bacteria (Kirchman et al. 1989) may alter the ratio of bacterial production to phytoplankton production. Furthermore, the time scales over which bacterial and phytoplankton production covary may change depending on the relative contribution of the various pathways by which phytoplankton carbon becomes available for bacterial consumption. Examples of these pathways include: continuous exudation by healthy algal cells (Sharp 1977); pulsed release by stressed or decaying phytoplankton blooms (Hammer \& Eberlein 1981); release by zooplankton excretion (Bidigare 1983); or 'sloppy feeding' by zooplankton (Lampert 1978).

The extent to which phytoplankton and bacterial growth are related also depends on how fast bacteria respond to changes in the environment. If bacteria responded slowly, for example, then changes in bacterial growth may appear unrelated to changes in phytoplankton production. A way to estimate this response time is to observe variations over time in the rate of bacterial production. However, measuning only bacterial production will overestimate the response time because the rates of several metabolic processes change before growth rate and bacterial abundance change. When pure cultures of bacteria shift from one 
growth rate to a higher one, the rate of macromolecular syntheses increases in a specific sequence (Ingraham et al. 1983). First, there is an increase in the rate of RNA synthesis in order to make more ribosomes for protein synthesis. The increase in RNA syntheses is followed by corresponding increases in rates of protein and DNA syntheses and eventually cell division. This sequence is reversed when bacteria shift to a lower growth rate. The period when the various rates of macromolecular syntheses are uncoupled is called unbalanced growth. If unbalanced growth can be detected, then a response time of bacteria can be estimated. Because the physical and chemical environment of bacterial assemblages in nature can vary over short time scales (Sieburth et al. 1977, Burney et al. 1982, Mopper \& Lindroth 1982), it is likely that unbalanced growth occurs

In this study we examined whether unbalanced growth can be observed with marine bacterial assemblages. Using seawater cultures of bacteria, we compared rates of bacterial DNA and protein syntheses with growth rate by measuring incorporation rates of thymidine and leucine, and changes in bacterial abundance over time. As predicted by the unbalanced growth model, rates of protein synthesis changed faster than rates of DNA synthesis prior to shifts in growth rate. The unbalanced growth model may explain why rates of thymidine and leucine incorporation occasionally do not covary.

\section{MATERIALS AND METHODS}

Sample collection and preparation of seawater cultures. Seawater cultures of bacteria (4 l) were prepared during May 1987 with water from the Chesapeake Bay and the Mid Atlantic Bight (exact locations are given in Table 1) and during December 1987 with water from the dock of the College of Marine Studies (Delaware Bay). Freshly collected samples were filtered through Nuclepore filters (1 $\mu \mathrm{m}$ pore-size) to reduce grazers, phytoplankton and detritus in relation to the bacteria. To promote bacterial growth (Ammerman et al. 1984) and reduce grazing by bacterivores passing the $1 \mu \mathrm{m}$ Nuclepore filter (Fuhrman \& MacManus 1984, Cynar et al. 1985), filtered samples were diluted 19 with 0.22 um pore-size filtered seawater from the same site (Tremaine \& Mills 1987). The diluent was prepared by filtration through either a Gelman Acruflux cartridge $(0.2$ um pore-size, fed by peristaltic pump) or a Millipore filter $(0.22 \mathrm{~mm}$ poresize, vacuum of $\leq 15 \mathrm{~cm} \mathrm{Hg}$ ). Incubations were in the dark at a constant temperature.

Bacterial growth: cell abundance, DNA and protein syntheses. Unbalanced growth was investigated by comparing changes in growth rate computed from increases in bacterial abundance with changes in relative rates of DNA and protein syntheses. Bacterial abundance was measured with epifluorescence microscopy of acridine orange-stained samples (Hobbie et al. 1977). Bacterial DNA and protein syntheses were estimated from incorporation rates of thymidine (TdR) (Fuhrman \& Azam 1982) and leucine (Leu) (Kirchman et al. 1985), respectively. Triplicate subsamples $(10 \mathrm{ml})$ were incubated for 30 min with either $\left[{ }^{3} \mathrm{H}\right] \mathrm{TdR}$ (5 nM final concentration [specific activity, $84.1 \mathrm{Ci} \mathrm{mmol}^{-1}$ ]) or $\left[{ }^{3} \mathrm{H}\right]$ Leu (10 nM final concentration; 2 nM radioactive [specific activity, $60.0 \mathrm{Ci} \mathrm{mmol}^{-1}$ ] and $8 \mathrm{nM}$ nonradioactive $L$ eu). Incubations were stopped by addition of $1 \mathrm{ml}$ of ice-cold $50 \%$ trichloroacetic acid (TCA) $(5 \%$ final concentration). TdR samples were placed on ice for 5 min to extract the total macromolecular fraction. Leu samples were placed in a dry bath at $85^{\circ} \mathrm{C}$ for 15 min to extract the protein fraction. Following extraction, samples were filtered through Millipore HA or Gelman GN-6 filters ( $0.45 \mu \mathrm{m}$ pore-size), rinsed with $1 \mathrm{ml}$ of $5 \%$ TCA and $1 \mathrm{ml}$ of deionized water and radioassayed. Abiotic absorption of radioactivity was corrected with TCA-killed controls. The utilization of dissolved organic matter during bacterial growth was estimated by measuring changes in the concentration of dissolved primary amines (DPA) using the fluorometric method described by Parsons et al. (1984). Estimates of DNA and protein produced were obtained by integrating rates of $\mathrm{TdR}$ and Leu incorporation over the course of the experiment. Standard deviations of the incorporation rates of the labeled substrates were propagated to calculate the uncertainty in these estimates.

Bacterial DNA and protein produced and rates of syntheses were also estimated from changes in particulate DNA and protein. Particulate DNA was measured fluorometrically (Paul \& Myers 1982). Duplicate subsamples $(10 \mathrm{ml})$ were filtered through Gelman GN-6 filters $(0.45 \mu \mathrm{m}$ pore size) and frozen immediately. Frozen filters were treated with $3 \mu$ of Triton $X-100(5 \%)$ in $3 \mathrm{ml}$ of $\mathrm{SSC}$ buffer $(0.154 \mathrm{M} \mathrm{NaCl}, 0.015 \mathrm{M}$ trisodium citrate, $\mathrm{pH} 7$ ) and sonicated for $30 \mathrm{~s}$. The samples were passed through $3 \mu \mathrm{m}$ Nuclepore filters to remove the shredded filters. Subsamples $(2 \mathrm{ml})$ of the filtrate were mixed with $1 \mathrm{ml}$ solution of Hoechst 33258 stain $\{0.15$ uM), and after $10 \mathrm{~min}$ in the dark, fluorescence was measured with a Turner fluorometer. Standard curves were obtained with calf thymus DNA (Sigma Chemical Co.) Protein content per cell ( $y$ ) was computed from average cell volume $(\mathrm{X})$ with the empirical relationship $y=88.6 X^{0.59}$, and corrected by adding $18 \%$ to account for amino acids not detected by the HPLC method used to derive this relationship (Simon \& Azam 1989). Average cell volumes were calculated from photographs of acridine orange-stained bacteria (Fuhrman 1981). The uncertainty associated with determining total protein 
produced using this method was estimated from the propagation of error of cell biovolume and bacterial abundance.

\section{RESULTS}

\section{TdR and Leu incorporation during changes in growth} rate

If unbalanced growth occurs in natural assemblages of bacteria, variations in the incorporation rates of TdR and Leu over time should reflect the sequence in which DNA and protein syntheses change during unbalanced growth. Prior to changes in growth rate, we expected to find (1) a lag between changes in the rates of Leu and TdR incorporation, and (2) fluctuations in the Leu: TdR ratio.

Bacterial growth in seawater cultures $(<1.0 \mu \mathrm{m}$ size fraction) from Chesapeake Bay and the Mid Atlantic Bight was examined during the spring of 1987 . In the Chesapeake Bay culture, Leu and $\mathrm{TdR}$ incorporation increased rapidly and then levelled off after $20 \mathrm{~h}$ (Fig. 1A). In the Mid Atlantic Bight culture, Leu and TdR incorporation was lower and incorporation rates did not increase rapidly until after $36 \mathrm{~h}$ (Fig. 2A). At both locations, Leu incorporation increased more rapidly than TdR incorporation as shown by variations in the ratio of Leu : TdR over time (Figs. $1 \mathrm{~B}$ and $2 \mathrm{~B}$ ). This ratio increased during increases in bacterial abundance after $26 \mathrm{~h}$ in the Mid Atlantic Bight culture (Fig. 2B) and decreased in the Chesapeake Bay culture after

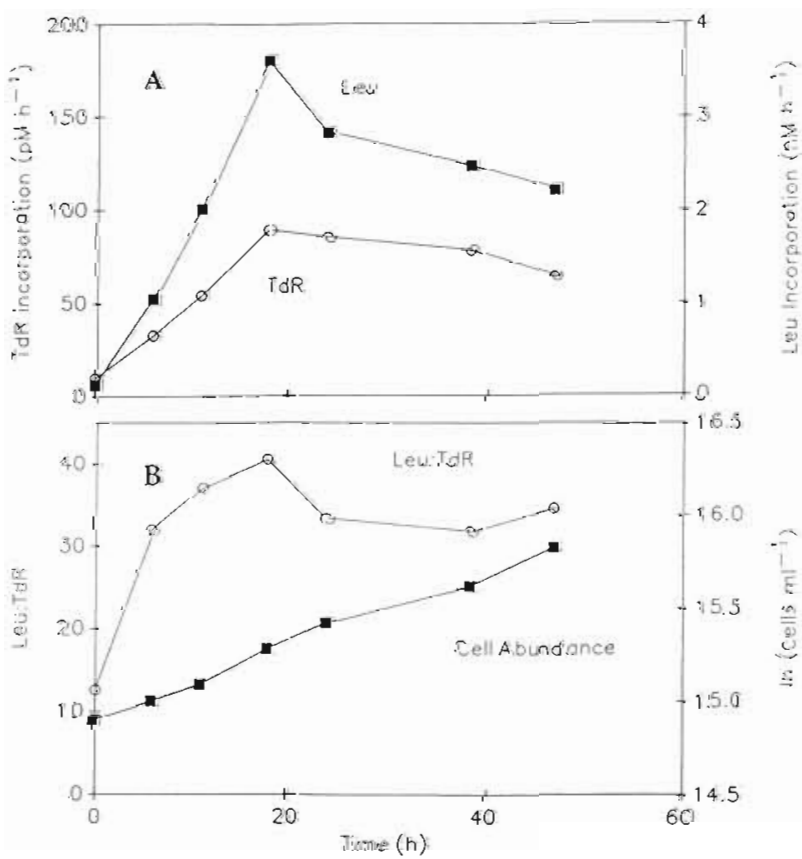

Fig. 1. Seawater culture from Chesapeake Bay during May 1989. (A) Incorporation rates of Leu and $T d R$ over time. (B) Bacterial abundance and ratio of Leu to TdR incorporation
$20 \mathrm{~h}$ (Fig. 1B), suggesting the uncoupling of DNA and protein syntheses that occurs prior to shifts in growth rate.

Experiments were repeated using Delaware Bay water during December 1987 The patterns of TdR and Leu incorporation was similar in duplicate cultures (Cultures A and B; Figs. 3 and 4 respectively). Rates of TdR incorporation increased rapidly after $20 \mathrm{~h}$ and then decreased near the end of the experiment (60 h) (Figs. $3 \mathrm{~A}$ and $4 \mathrm{~A}$ ). There were 2 peaks of Leu incorporation, one centered at $30 \mathrm{~h}$ and another at $60 \mathrm{~h}$ (Figs. 3A and $4 \mathrm{~A})$. In both cultures, bacterial abundance increased rapidly over the first $40 \mathrm{~h}$ and then more slowly towards the end of the experiment (Figs. $3 B$ and 4B). Concentration of DPA increased slightly at the beginning of the experiment but then decreased rapidly as bacterial abundance increased, suggesting rapid utilization by bacteria (Fig. 3C).

Variations in the Leu $T d R$ ratio showed that, as predicted by the unbalanced growth model, Leu incorporation increased faster than $\mathrm{TdR}$ incorporation prior to increases in growth rate and decreased faster before decreases in growth rate. We considered that the growth rate had changed when the slopes were significantly different. For example, in Culture A the growth rates were $0.021 \pm 0.008,0.096 \pm 0.009$ and $0.016 \pm$ 0.004 (Fig. 3B). The Leu: TdR ratio was considered to have varied when the ratio changed by at least a factor of 2. In Culture A, prior to a shift-up at $16 \mathrm{~h}$ from 0.021 to $0.096 \mathrm{~h}^{-1}$, there was an increase in the Leu: TdR at 8 h (Fig. 3B). Similarly, prior to a shift-down from 0.096

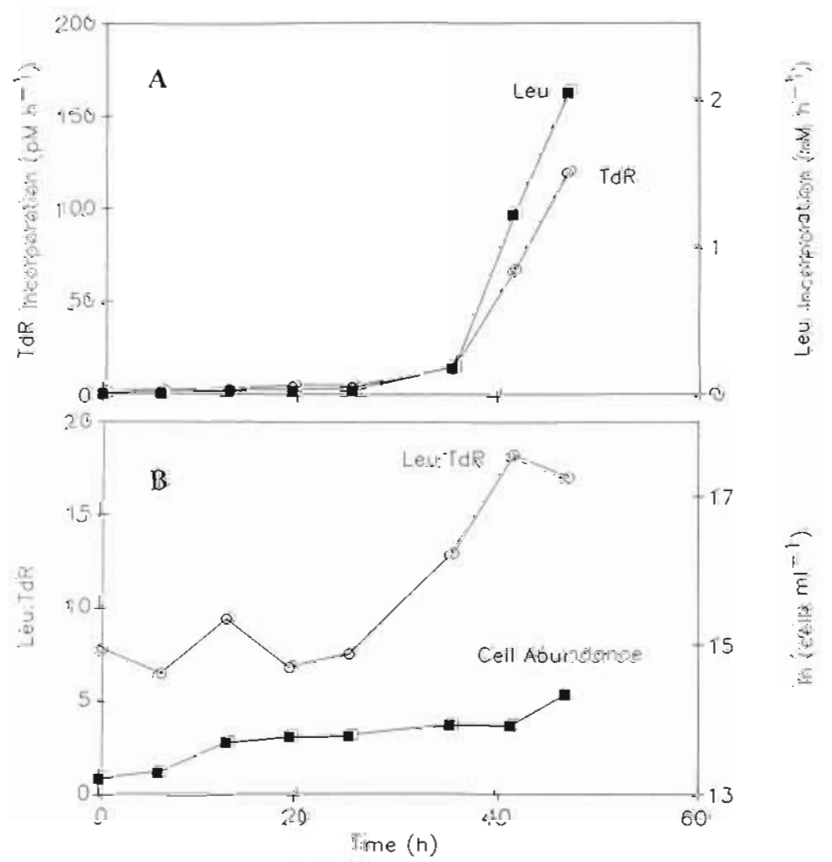

Fig 2. As Fig. 1 but for seawater culture from the Mid Atlantic Bight 

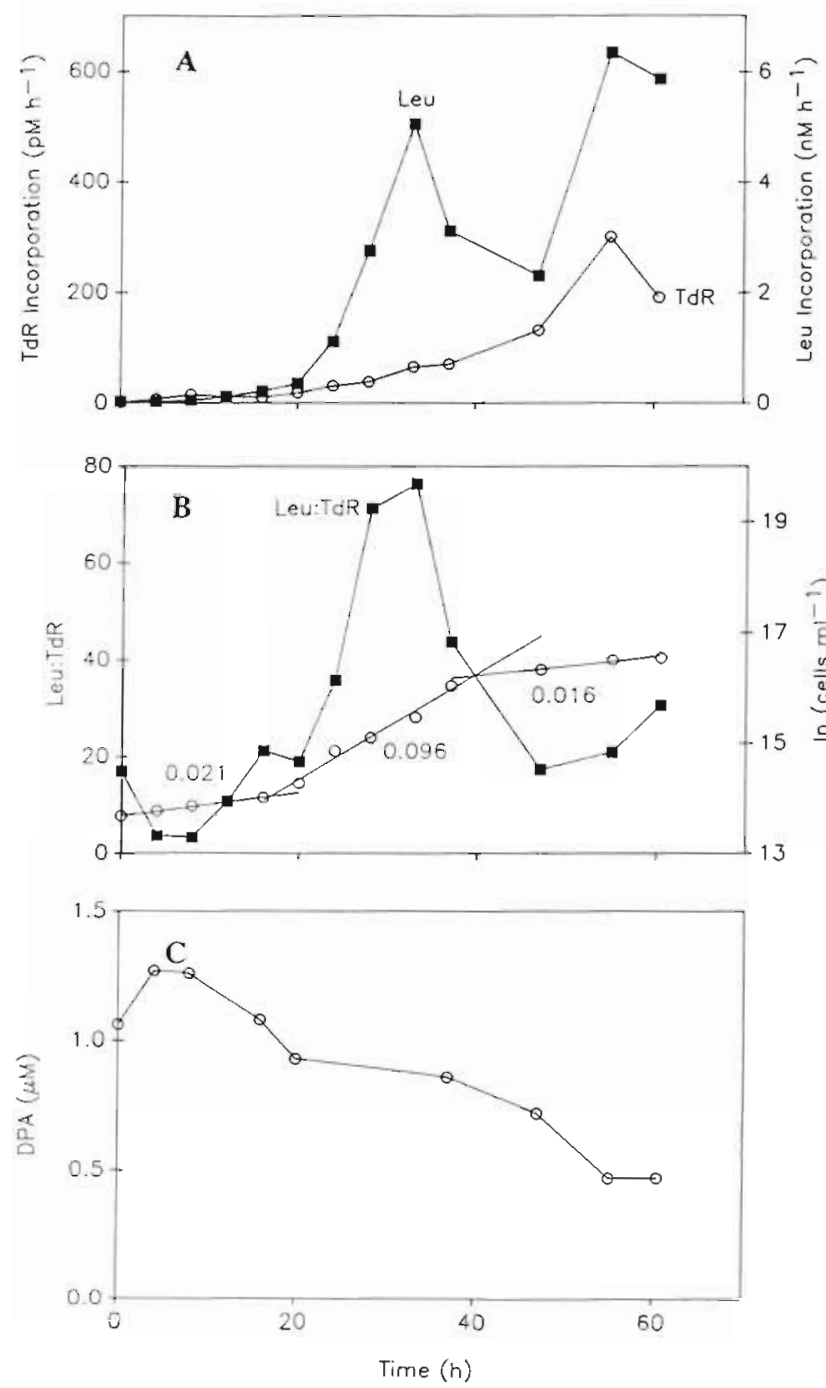

Fig. 3. Seawater Culture A from Delaware Bay during December 1987. (A) Incorporation rates of Leu and TdR over time. Standard errors were less than $5 \%$. (B) Specific growth rate $(\mu)$ and the leucine to thymidine ratio (Leu. TdR) over time. Values of the 3 growth rates $(0.021 \pm 0.008,0.096 \pm$ 0.009 and $0.016 \pm 0.004$ ) are included near the segment of the curve used to compute them. (C) Concentration of dissolved primary amines (DPA) over time

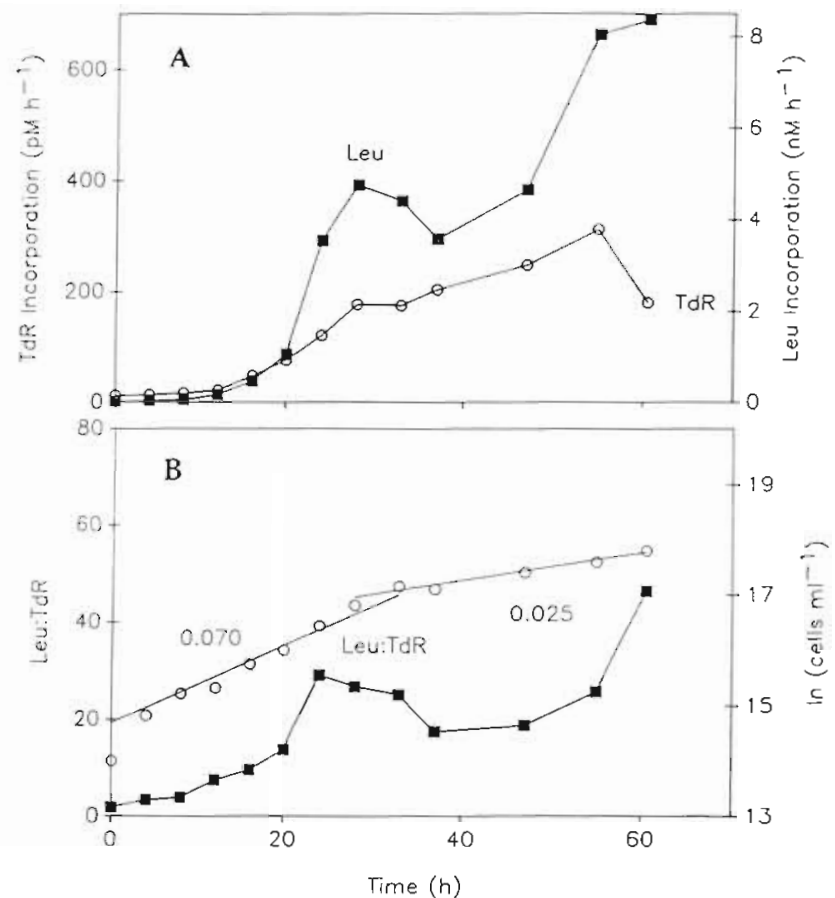

Fig. 4. As Fig. 3 but for growth Culture B. Concentration of DPA was not measured in this culture

to $0.016 \mathrm{~h}^{-1}$ after $37 \mathrm{~h}$, the Leu: TdR ratio decreased after $33 \mathrm{~h}$ (Fig. $3 \mathrm{~B}$ ). In Culture $\mathrm{B}$, the Leu: $\mathrm{TdR}$ ratio decreased after $24 \mathrm{~h}$ before a decrease in growth rate at $33 \mathrm{~h}$ (Fig. 4B). The delays between changes in the Leu : TdR ratio and corresponding shifts in growth rates were 8 and $4 \mathrm{~h}$ for Culture $\mathrm{A}$, and $9 \mathrm{~h}$ for Culture B (Table 1). These lags were shorter than the generation time preceding the shift (Table 1).

In Culture $A$, rates of DNA synthesis were also computed from changes in particulate DNA, and rates of protein synthesis were estimated from changes in cell biovolume. Rates of DNA synthesis derived from changes in particulate DNA were calculated only for the last 5 time points to avoid any interference by the possible presence of detrital DNA (Table 2). Total DNA

Table 1. Response time of bacteria calculated as the lag between variations in the Leu : TdR ratio and shifts in generation time

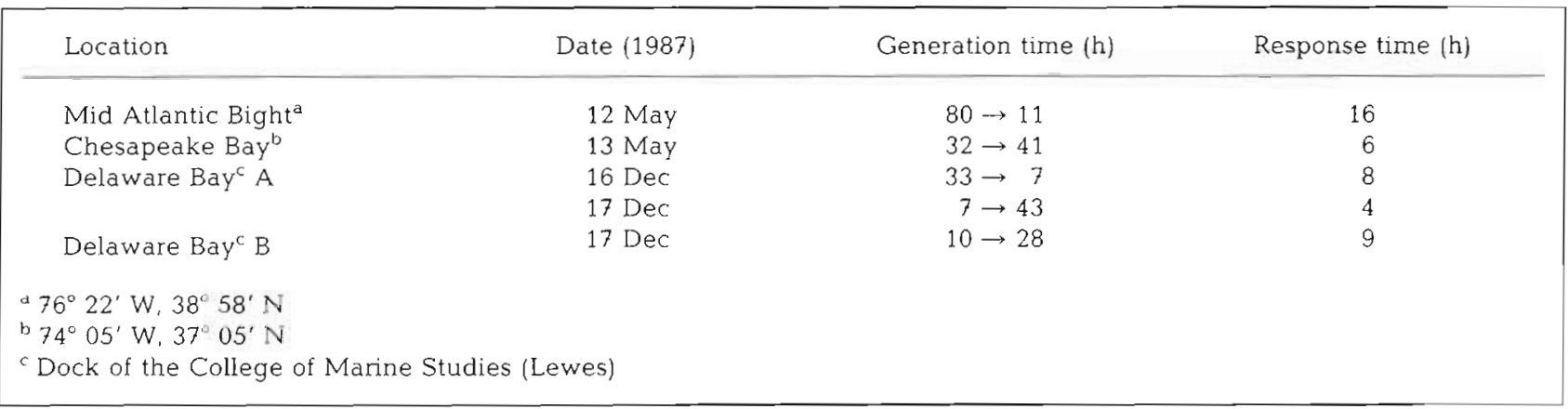


Table 2. Average biovolume, DNA per biovolume, DNA per cell and C: DNA ratio of bacteria in Delaware Bay seawater Culture A during last $28 \mathrm{~h}$ of the experiment

\begin{tabular}{|ccccc|}
\hline Time $(\mathrm{h})$ & $\begin{array}{c}\text { Average biovolume } \\
\left(\mu \mathrm{m}^{3}\right) / \text { cell } \pm \mathrm{SE}\end{array}$ & $\begin{array}{c}\text { DNA biovolume } \\
\left(\mathrm{fg}^{\mathrm{k}} \mu \mathrm{m}^{3}\right)\end{array}$ & $\begin{array}{c}\text { DNA/cell } \\
(\mathrm{fg})\end{array}$ & C: DNA $^{\mathrm{b}}$ \\
\hline 33 & $0.41 \pm 0.16$ & 15.41 & 6.32 & 3.16 \\
37 & $0.15 \pm 0.03$ & 26.73 & 4.01 & 4.99 \\
47 & $0.13 \pm 0.03$ & 34.77 & 4.52 & 4.42 \\
55 & $0.40 \pm 0.19$ & 11.83 & 4.73 & 6.08 \\
61 & $0.38 \pm 0.10$ & 8.66 & 3.29 & \\
${ }^{\mathrm{a}} \mathrm{n}=50$ & & & \\
${ }^{\mathrm{b}}$ Assuming $20 \mathrm{fg} \mathrm{C}$ cell $^{-1}$ (Lee \& Fuhrman 1987) & & & \\
\hline
\end{tabular}

concentration at the end of the experiment derived fluorometrically ( $50 \mu \mathrm{g} \mathrm{l}^{-1}$ ) was close to the value calculated from TdR incorporation integrated over the duration of the experiment $\left(65 \pm 3 \mu \mathrm{g} \mathrm{l}^{-1}\right)$. Rates of protein synthesis derived from changes in biovolume and cell abundance agreed with those obtained from rates of Leu incorporation $(\mathrm{r}=0.69, \mathrm{n}=12, \mathrm{p}<0.05$ ) (Fig. 5). In addition, total bacterial protein produced $(877 \pm 440$ $\mu \mathrm{g}^{-1}$ ), based on average cell biovolume, was within a factor of 2 of that derived from Leu incorporation (491 $\pm 6 \mu \mathrm{g} \mathrm{l}^{-1}$ ) assuming $8.8 \%$ Leu molar fraction of protein (Kirchman et al. 1986) and an isotope dilution factor of 2.3 (Simon \& Azam 1989).

\section{Variations in DNA and protein content of bacteria}

Variations in the DNA and protein (cell volume) amounts in cells paralleled changes in the rates of Leu and $T d R$ incorporation. Average cell volumes were maximal during the period of highest growth rate and near the end of the experiment (Fig. 6A) coinciding with maximal rates of Leu incorporation (Fig. 3A). During these periods, the standard error of cell volume was

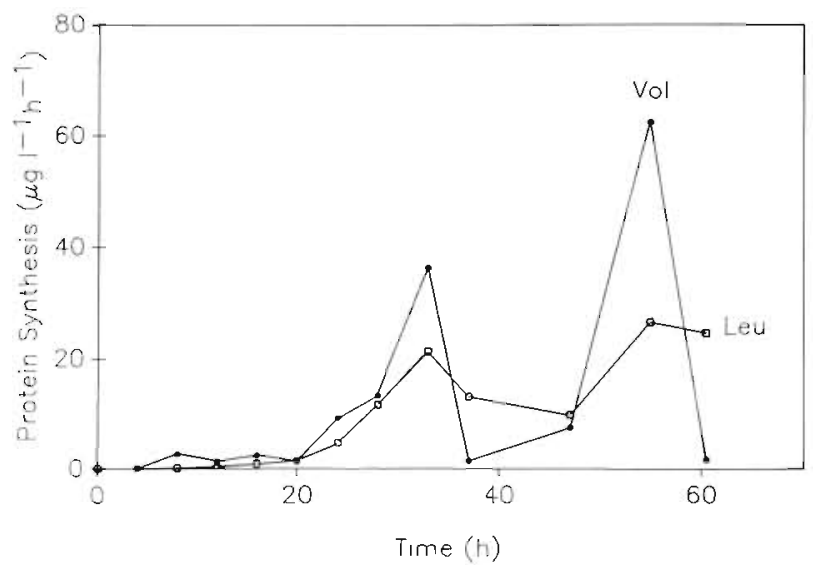

Fig. 5. Rates of protein synthesis ( $\left.\mu \mathrm{g} \mathrm{I}^{-1} \mathrm{~h}^{-1}\right)$ over time calculated from changes in average biovolume (Vol) and leucine incorporation (Leu) also large because of a large variation in sizes (Fig. 6A). Bacterial protein (biovolume per liter) increased rapidly over the first $33 \mathrm{~h}$ of the experiment, and then slowed down during the shift-down period between 37 and $47 \mathrm{~h}$ (Fig. 6B). Smaller cells (Fig. 6A) with higher concentrations of DNA per biovolume were dominant during this period of unbalanced growth prior to the decrease in growth rate (Table 2). As the population appeared to shift up again near the end of the experiment (Fig. 3B), cell volumes increased again, and the ratio of DNA per unit of biovolume decreased (Table 2). Average DNA per cell varied from 4.23 to $6.32 \mathrm{fg}$ (Table 2). Assuming $20 \mathrm{fg} \mathrm{C}$ per cell (Lee \& Fuhrman
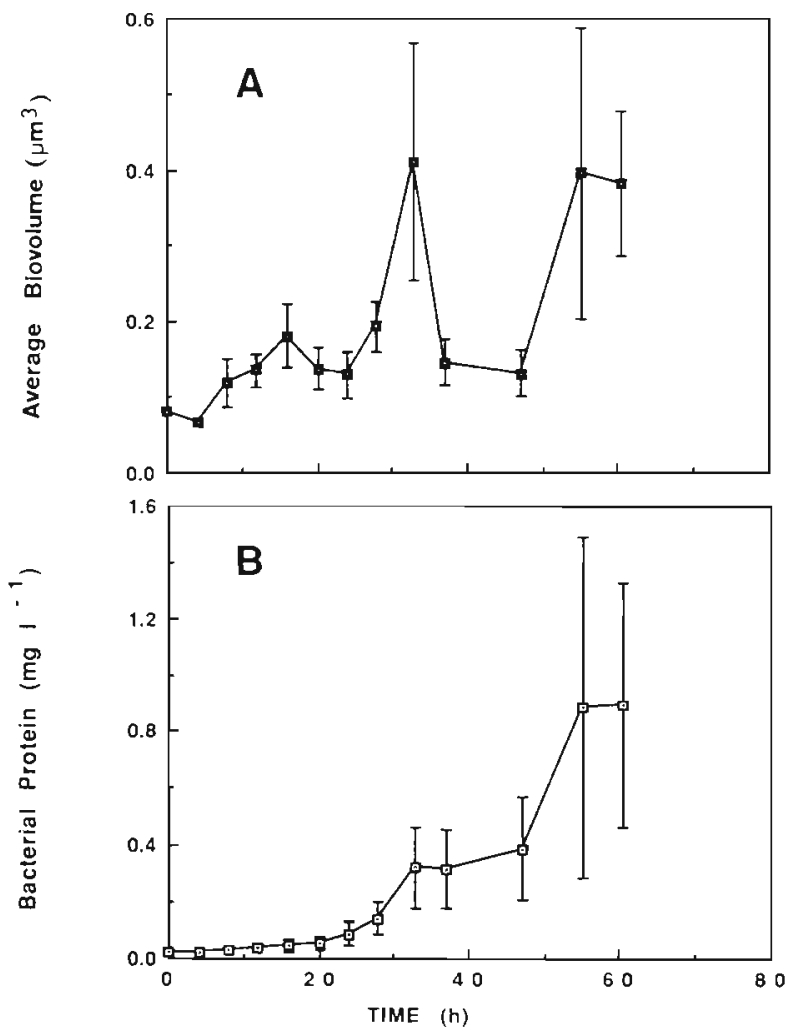

Fig. 6. (A) Variations of average biovolume $\left(\mu \mathrm{m}^{3}\right)$ over time. (B) Bacterial protein ( $\mathrm{mg} \mathrm{l}^{-1}$ ) computed from average cell volumes. Error bars represent standard errors 
$1987)$, the C:DNA ratio ranged from 3.16 to 6.08 (Table 2).

\section{DISCUSSION}

This study suggests that natural assemblages of bacteria undergo unbalanced growth that can be detected by measuring rates of $\mathrm{TdR}$ and Leu incorporation. In seawater cultures, uncoupling of DNA and protein syntheses occurred prior to changes in growth rate. The sequence in which rates of Leu and TdR incorporation changed during bacterial growth (Figs, 3A and 4A), and the variations in the Leu $T d R$ ratio prior to shifting growth rates (Figs. $3 \mathrm{~B}$ and $4 \mathrm{~B}$ ) were consistent with the sequence in which protein and DNA syntheses vary during unbalanced growth in pure cultures (Ingraham. et al. 1983). Furthermore, variation of average DNA per cell (Table 2) and average cell biovolume (Fig. 6A) agreed with the expected composition of cells during shift-up and shift-down. Similar variations in the DNA content of bacteria have been observed by Cho \& Azam (1988) during growth in seawater cultures. The average DNA per cell calculated from particulate DNA was 4.57 $\pm 0.50 \mathrm{fg} \mathrm{cell}^{-1}$ which is within a factor of 2 of those reported for natural assemblages of bacteria from a variety of freshwater $\left(7.1 \mathrm{fg} \mathrm{cell}^{-1}\right.$; McCoy \& Olson 1985) and marine $\left(5.55 \mathrm{fg}\right.$ cell $^{-1}$; Paul et al. 1985) environments. The average $\mathrm{C}$ : DNA ratio of bacteria was $4.58 \pm 0.58$ (Table 2 ) suggesting that natural marine bacteria have a higher DNA content than cultured bacteria (Fuhrman et al. 1986).

A potential problem with the $\mathrm{TdR}$ method used in this study is that if some of the $T d R$ incorporated into the macromolecular fraction was incorporated into fractions other than DNA (Hollibaugh 1988), the result would be an overestimate of the rate of DNA synthesis. Total DNA synthesized over the course of the experiment estimated from $T d R$ incorporation was $65 \pm 3 \mu \mathrm{g}$ $\mathrm{I}^{-1}$ which is higher than the value of $50 \mu \mathrm{g} \mathrm{l}^{-1}$ derived from changes in particulate DNA, suggesting some metabolism of the TdR. Nevertheless, the values obtained from these independent methods are relatively close, suggesting that the TdR method gives a good estimate of DNA synthesis.

Rates of protein synthesis estimated from Leu incorporation and those computed from changes in cell biovolume were remarkably close (Fig 5). This good agreement implies that our assumption about isotope dilution was correct. Assuming isotope dilution factors of 2 and 3 , the total bacterial protein produced over the course of the experiment based on rates of Leu incorporation ranged from $216 \pm 6$ to $592 \pm 6 \mu \mathrm{g} \mathrm{l^{-1 }}$. These values are within a factor of 4 and 2 from the value calculated from average biovolume and cell abundance $\left(877 \pm 440 \mathrm{ug} \mathrm{l}^{-1}\right)$. This result implies that the isotope dilution for Leu is at most 4 -fold. Simon \& Azam (1989) consistently measured, in various environments, a 2fold isotope dilution which may be caused by intracellular pools of Leu.

Previous studies have observed that there is usually a high correlation between rates of $T d R$ and Leu incorporation (Chin-Leo \& Kirchman 1988, Kirchman \& Hoch 1988, Hollibaugh \& Wong unpubl.) which suggests that bacterial assemblages were in balanced growth. The variation in Leu incorporation not explained by variation in TdR incorporation, however, can be as much as $55 \%$ (Kirchman et al. 1989), and occasionally Leu and TdR incorporation do not covary (McDonough et al. 1986). Some of the lack of covariance is due to methodological problems, such as nonspecific incorporation of TdR into protein (McDonough et al. 1986). Another explanation is that these bacterial assemblages may have been in unbalanced growth. That is, the Leu: TdR ratio varied because the assemblage was responding to changes in the environment of the bacteria. Unbalanced growth needs to be considered when different measures of bacterial production are compared. Christian et al. (1982) found significant differences in bacterial growth rates of batch cultures when estimated by various methods and assumptions about the growth state of the bacteria.

Because it is difficult to follow a discrete assemblage of bacteria in situ, it is not yet possible to prove unequivocally that variations in the Leu : TdR ratio are due to unbalanced growth. The seawater cultures used in this study are a compromise between a controlled system of laboratory cultures and the complex diversity of natural assemblages. A potential drawback of extending findings derived from seawater cultures to nature is that 'weed' species may be selected by the experimental conditions with behavior not representative of a mixed assemblage. Ferguson et al. (1984) suggested that species selection may occur in these cultures because the percentage of bacteria capable of growing on agar plates increased after differential filtration and confinement. In this study, even if the species composition changed, the results indicate that the behavior of the assemblage still followed the predictions of the unbalanced growth model. The incorporation of Leu and TdR always varied when growth rate changed. It is unlikely that variations in the Leu: TdR ratio caused by the behavior of a single species would be timed such that it would coincide with the shift in growth rate of the entire bacterial assemblage as measured by changes in bacterial numbers. However, the average response of a mixed assemblage of bacteria, composed of various species, each responding at a different rate may 'smear' the measured response. For example, in the cultures from Chesapeake Bay, the Mid Atlantic Bight (Fig. 1) and those examined by Kirchman et al. 
(1986), even though Leu incorporation always increased faster than $T d R$ incorporation, a delay between changes in Leu and TdR incorporation was not always observed.

In the experiments reported here, substrate composition and concentration are probably important in controlling growth rate (Kirchman 1990). The decline of DPA concentrations coincided with increases in bacterial abundance and probably reflect the rapid utilization of labile dissolved organic matter for growth (Fig. 3C). In nature, unbalanced growth probably results from variation in the DOM supply, because that appears to be limiting bacterial production (Kirchman 1990). Several authors reported non-steady state growth of bacteria which they attributed to variations in DOM supply caused by the spatial and temporal heterogeneity of the phytoplankton (Hanson \& Lowery 1983, Hanson et al. 1986, Robarts et al. 1986). The extent of unbalanced growth will depend on the response time of bacteria relative to the frequency and magnitude of changes in the DOM supply. For example, if changes in labile DOM 'released' by phytoplankton are small or slow relative to the ability of bacteria to respond, then phytoplankton and bacterial production will covary. On the other hand, if changes are large or fast compared with the bacterial response time, we are likely to sample bacterial assemblages during periods of shifting growth rates. Bacterial production will then appear uncoupled from phytoplankton production.

We can speculate about which type of DOM release is likely to cause unbalanced growth in natural bacterial assemblages. Because unbalanced growth reflects the initial adjustment of the cells to a change in their growth environment, the delays between changes in the Leu:TdR ratio and corresponding shifts in growth rates may be interpreted as the response time of bacteria. The response time of bacteria in this study ranged from 4 to $16 \mathrm{~h}$ (Table 1). If these response times are representative of those in nature, then variations in DOM due to short-term events (minutes) would be too fast to be detected by bacteria. Although, the ecological significance of patches of high DOM concentration released by large zooplankton remains a matter of debate (Currie 1984, Lehman \& Scavia 1984), the lifetime of these patches is probably too short to cause unbalanced growth in bacteria. Long-term changes, such as those caused by seasonal variation in primary production, are also unlikely to cause unbalanced growth because the change is very slow compared to the bacterial response time. Diel variations in primary production and inefficient grazing appear most likely to cause unbalanced growth in bacterial assemblages. These diel variations are on the same time scale as the response time measured by this study.

Comparison of relative rates of DNA and protein syntheses during the growth of natural assemblages of bacteria in seawater cultures suggest that unbalanced growth occurs and can be observed in mixed assemblages. Because the coupling between bacterial growth and various environmental factors depends on the response time of the bacteria, measurements of unbalanced growth may be useful in identifying the factors that regulate bacterial growth in nature. Furthermore, if non-steady state growth is common in nature, knowledge of the metabolic state of bacteria will be critical for interpreting the various measures of bacterial growth.

Acknowledgements. This research was supported in part by National Science Foundation grants OCE 8310407 (awarded to M. Tyler, R. Biggs, and L. Harding), OCE 8314607, OCE 8520278 (awarded to R. Rivkin), and OCE 8614170 and National Oceanographic and Atmospheric Administration sea grant NA86AA-D-SG040 (awarded to D. L. K.).

\section{LITERATURE CITED}

Ammerman, J. W., Fuhrman, J. A., Hagström, A., Azam, F. (1984). Bacterioplankton growth in seawater: I. Growth kinetics and cellular characteristics in seawater cultures. Mar. Ecol. Prog. Ser. 18: 31-39

Bidigare, R. R. (1983). Nitrogen excretion by marine zooplankton. In: Carpenter, E. J., Capone, D. G. (eds.) Nitrogen in the marine environment. Academic Press, New York, p. $285-409$

Burney, C. M., Davis, P. K., Johnson, K. M., Sieburth, J. McN. (1982). Diel relationships of microbial trophic groups and in situ dissolved carbohydrate dynamics in the Caribbean Sea. Mar. Biol. 67: 311-312

Chin-Leo, G., Kirchman, D. L. (1988). Estimating bacterial production in marine waters from the simultaneous incorporation of thymidine and leucine. Appl. environ. Microbiol. 54: 1934-1939

Cho, B. C., Azam, F. (1988). Heterotrophic bacterioplankton production measurement by the tritiated thymidine incorporation method. Arch. Hydrobiol. Beih. Ergebn. Limnol. 31: 153-162

Christian, R. E., Hanson, R. B., Newell, S. Y (1982). Comparison of methods for measurement of bacterial growth rates in mixed batch cultures. Appl. environ. Microbiol. 43: $1160-1165$

Cole, J. J., Findlay, S., Pace, M. L. (1988). Bacterial production in fresh and saltwater ecosystems: a cross-system overview. Mar. Ecol. Prog. Ser. 43: 1-10

Currie, D. J. (1984). Microscale nutrient patches: do they matter to the plankton? Limnol. Oceanogr. 29: 211-214

Cynar, S. J., Estep, K. W., Sieburth, J. McN. (1985). The detection and characterization of bacterial-sized protists in 'protist-free' filtrates and its potential impact on experimental marine ecology. Microb. Ecol. 11: 288-288

Ducklow, H. W. (1983). Production and fate of bacteria in the oceans. Bioscience 33: 494-501

Ferguson, R. L., Buckley, E. N., Palumbo, A. V. (1984). Response of marine bacterioplankton to differential filtration and confinement. Appl. environ. Microbiol. 47: 49-55

Fuhrman, J. A. (1981). Influence of method on the apparent 
size distribution of bacterioplankton cells: epifluorescence microscopy compared to scanning electron microscopy. Mar. Ecol. Prog. Ser. 5: 103-106

Fuhrman, J. A., Azam, F. (1982). Thymidine incorporation as a measure of heterotrophic bacterioplankton production in marine surface waters; evaluation and field results. Mar. Biol. 66: 109-120

Fuhrman, J. A., Ducklow, H. W., Kirchman, D. L., Hudak, J., McManus, G. B., Kramer, J. (1986). Does adenine incorporation into nucleic acids measure total microbial production? Limnol. Oceanogr. 3: 627-636

Fuhrman, J. A., McManus, G. B. (1984). Do bacteria-sized marine eukaryotes consume significant bacterial production? Science 224: 125

Hammer, K. D., Eberlein, K. (1981). Parallel experiments with Thalassiosira rotula in outdoor plastic tanks: development of dissolved free amino acids during an algae bloom. Mar. Chem. 10: 533-544

Hanson, R. B., Lowery, H. K. (1983). Nucleic acid synthesis in oceanic microplankton from the Drake Passage, Antarctica: evaluation of steady-state growth. Mar. Biol. 73: 79-89

Hanson, R. B., Pomeroy, L. R., Murray, R. E. (1986), Microbial growth rates in a cold-core Gulf Stream eddy of the northwestern Sargasso Sea. Deep Sea Res. 33: 427-446

Hobbie, J. E., Daley, R. J., Jasper, S. (1977). Use of Nuclepore filters for counting bacteria by fluorescence microscopy Appl. environ. Microbiol. 33: 1225-1228

Hollibaugh, J. T (1988). Limitations of the $\left[{ }^{3} \mathrm{H}\right.$ thymidine method for estimating bacterial productivity due to thymidine metabolism. Mar. Ecol. Prog. Ser. 43: 19-30

Ingraham, J. L., Maaloe, O., Neidhardt, F. C. (1983). Growth of the bacterial cell. Sinauer Assoc., Sunderland, Massachusetts

Kirchman, D. L. (1990). Limitation of bacterial growth by dissolved organic matter in the subarctic Pacific. Mar. Ecol. Prog. Ser. 62: 47-54

Kirchman, D. L., Hoch, M. P. (1988). Bacterial production the Delaware Bay estuary estimated from thymidine and leucine incorporated rates. Mar Ecol. Prog. Ser. 45: $169-178$

Kirchman, D. L., K'ness, E., Hodson, R. (1985). Leucine incorporation and its potential as a measure of protein synthesis by bacteria in natural aquatic systems. Appl. environ. Microbiol. 49: 599-607

Kirchman, D. L., Murray, R. E., Hodson, R. E. (1986). Rates of DNA and protein synthesis by heterotrophic bacteria in aquatic environments: a comparison between the thymidine and leucine approaches. In: Magusàr, F., Gantar, M. (eds.) Proc. Fourth International Symposium on Microbial Ecology, Ljubljana, Yugoslavia. Slovene Society for Microbiology, Ljubljana, p. 631-638

Kirchman, D. L., Van Wambeck, F., Soto, Y., Bianchi, M

This article was presented by Dr S. Y Newell, Sapelo Island, Georgia, USA
(1989). Bacterial production in the Rhône River plume: effect of mixing on relationships among microbial assemblages. Mar Ecol. Prog. Ser. 53: 267-275

Lampert. W (1978). Release of dissolved organic carbon by grazing zooplankton. Limnol. Oceanogr. 23: 831-834

Lee, S. Fuhrman, J. A. (1987). Relationships between biovolume and biomass of naturally derived marine bacterioplankton. Appl. environ. Microbiol. 53: 1298-1303

Lehman, J. T., Scavia, D. (1984). Measuring the ecological significance of microscale nutrient patches. Limnol. Oceanogr. 29: 214-216

McCoy, W. F., Olson, B. H. (1985). Fluorometric determination of the DNA concentration in municipal drinking water Appl. environ. Microbiol. 49: 811-817

McDonough, R. J., Sanders, R. M., Porter, K. G., Kirchman, D L. (1986). Depth distribution of bacterial production in a stratified lake with an anoxic hypolimnion. Appl. environ. Microbiol. 52: 992-1000

McManus, G. B., Peterson, W. T (1988). Bacterioplankton production in the nearshore zone during upwelling off central Chile. Mar. Ecol. Prog. Ser. 43: 11-17

Mopper, K. Lindroth, P. (1982). Diel and depth variations in dissolved free amino acids and ammonium in the Baltic Sea determined by shipboard HPLC analysis. Limnol. Oceanogr. 27: 336-347

Parsons, T. R., Maita, Y., Lalli, C. M. (1984). A manual of chemical and biological methods for seawater analysis. Pergamon Press, Oxford

Paul, J. H., Myers, B. (1982). Fluorometric determination of DNA in aquatic microorganisms by use of Hoechst 33258 Appl. environ. Microbiol. 43: 1393-1399

Paul, J. H., Jeffrey, W. H., DeFlaun, M. (1985). Particulate DNA in subtropical oceanic and estuarine planktonic environments. Mar. Biol. 90: 95-101

Robarts, R. D., Wicks, R. J., Septhon, L. M. (1986). Spatial and temporal variations in bacterial macromolecule labeling with [methyl $-{ }^{3} \mathrm{H}$ ] thymidine in a hypertrophic lake. Appl. environ. Microbiol. 52: 1368-1372

Sharp, J. H. (1977). Excretion of organic matter by marine phytoplankton: do healthy cells do it? Limnol. Oceanogr 27. 381-399

Sieburth, J. McN., Johnson, K. M., Burney, C. M., Lavoie, D M. (1977). Estimation of in situ rates of heterotrophy using diurnal changes in organic matter and growth rates of picoplankton in diffusion culture. Helgoländer Wiss. Meeresunters. 30: 565-574

Simon, M., Azam, F. (1989). Protein content and protein synthesis rates of planktonic marine bacteria. Mar Ecol. Prog. Ser. 51. 201-213

Tremaine, S. C., Mills, A. L. (1987). Tests of the critical assumptions of the dilution method for estimating bacterivory by microeucaryotes. Appl. environ. Microbiol. 53: $2914-292$

Manuscript first received: September 26, 1989

Revised version accepted: January 11, 1990 